\title{
Learning Approaches of Undergraduate Computer Technology Students: Strategies for Improvement
}

\author{
SUSEELA MALAKOLUNTHU \\ University Malaya \\ Corresponding author: suseela@um.edu.my
}

\author{
ALICE JOSHUA \\ Sunway University
}

\begin{abstract}
Purpose - In recent times, quality of graduates and their performance has been questioned. Students' performance is an indicator of the kind of approach (deep or surface) that is taken. This study investigates the kind of undergraduates take in their learning processes.
\end{abstract}

Methodology - This quantitative survey used Revised Two-Factor Study Process Questionnaire (R-SPQ-2F). Sixty-three students participated in the study.

Findings - Results showed no significant difference between the types of approach by gender, nationality, year of study, and major. However, the rank ordering of the mean value indicated that almost all the students who participated in the study did not possess a deep approach to learning. The Pearson's $r$ analysis revealed a weak negative statistical correlation between the deep and surface approaches to learning and weak positive statistical correlation between surface strategy and deep approach. However, a significant relationship between deep strategy and deep approach $\left(r=.903^{* *}\right.$, $p<.01$ ) was found.

Significance - The lack of deep approach to learning among students can be attributed to factors such as the conditions of learning, professional capacity of teachers, and lack of instructional rigor in the program or coursework. It is imperative that emphasis is placed 
on using deep approaches to learning in the university courses so that deep learning experiences are created for students.

Keywords: Higher education, computer technology, learning approaches.

\section{INTRODUCTION}

Growing concern has been shown over the quality of graduates produced by public and private Higher Education Institutions in Malaysia. The institutions are criticized for producing graduates who lack qualities such as critical thinking, aptitude for self-managed learning, reflective thinking, and ability to solve novel problems at the workplace (Khoo, 2001; Koo, Pang, \& Mansur, 2006). A tracer study by the Ministry of Human Resources Malaysia conducted in 2006 showed that $30.7 \%$ of graduates remained unemployed six months after their graduation while 5.6\% were still awaiting job placement (Tan, 2007). This situation has been attributed to graduates' lack of generic skills, inability to communicate effectively, inability to participate in problem-solving activities, disinterest in scouting for new ideas, and narrow view of the issues at hand, and resorting to quick fixes. The concern over the employability of local graduates and their attributes reflect on to the quality of higher education (Woo, 2006). And this leads to the question of curriculum, teaching methodology, course structure and content, learning environment, quality of teaching and teachers, and student context and disposition towards learning.

Among the numerous competencies expected by employers, competency in Information and Communications Technology (ICT), business communication, critical thinking, and problem solving skills in the workplace top the list (National Higher Education Research Institute, 2007). While government and private sector expectations are increasing, the quality of student performance in college is not encouraging. For example, student performance at the Computing School at one of the private university colleges under study has not shown improvement since 2008. What is the reason for this performance stagnation? Are the students really interested in studying? Is there a conducive learning environment that can boost student motivation to learn? Are there other problems related 
to the teaching-learning process hindering their learning capability? These are some of the questions that needed to be answered in order to help students improve in their intellectual capacity and work performance.

\section{EMPIRICAL STUDIES ON APPROACHES TO LEARNING}

Some of the factors that influence students' learning approaches are course context, preferred learning environment, course content and demands of the learning tasks, and the motivation level of students (Biggs 1987; Domye, 2000; Jacobs \& Newstead, 2000). In a study that focused on Asian students, Kember and Gow (1991) identified two factors which influenced students' approach to learning, i.e., as motivation and the learning-teaching environment. This was reiterated by Entwistle $(1987,1991)$ who concluded that perception of the learning environment influences how a student learns.

Raadt, Hamilton, and Listor (2005) used Biggs, Kember and Leung's (2001) Revised Study Process Questionnaire (R-SPQ-2F) and Paper Folding technique to conduct a study on 175 introductory programming course students across 11 tertiary institutions in Australia, New Zealand, and Scotland. The results showed students were not strongly aligned with either deep or surface approaches to learning. But there existed significant correlation between marks, learning approach and a negative trend between marks and surface approach to learning. A cross-sectional study conducted on 463 medical and dental students in Malaysia using the R-SPQ-2F showed significant positive correlation between deep approaches to learning and academic achievement, and surface approaches and low academic achievements (Kumar \& Sethuraman 2007). Kember and Gow's (1991) study on 4863 students using Biggs's SPQ (1987) identified curriculum design, assessment requirements, workload, teaching approach and student's perception of relevance and interest in the course as having an impact on learning approaches adopted by the students. Zeegers (2001) who used Biggs' SPQ in a longitudinal study showed consistent positive correlation between deep approach to learning and assessment outcomes. Gijbels and Dochy's (2006) study showed that deep approach students preferred higher-order 
thinking assessment tasks and non-conventional assessment. To identify cultural influence on learning approaches, Ling et al. (2005) who used Biggs' SPQ on 100 Statistics course students found no significant difference between approaches to learning among Australian students and Asian students. However, students enrolled at different levels of study (foundation, undergraduate and postgraduate) showed differences in their approaches.

\section{THEORETICAL FRAMEWORK}

Student's approach to learning, either deep or surface, is considered a factor that influences the learning process and outcome of a student (Biggs, 1987, 1999; Biggs et al., 2001). Biggs and his colleagues (2001) in their '3P' (presage-process-product) model of teaching and learning explain how students' approaches to learning can be seen as a total system where student factors, teaching context, learning-focused activities, and the learning outcomes mutually interact. Students' prior knowledge and ability, teachers' pedagogical content knowledge, the nature of the curriculum, methods of assessment, institutional climate and procedures interact to determine the on-going approach to learning, which in turn determines the output. Figure 1 adapted from the ' $3 \mathrm{P}$ ' model of teaching and learning, shows that the teaching context and the learning-focused activities influence students' disposition and drive towards quality learning. They are mutually linked and together they produce the desired learning outcomes. When the teaching context is changed and the teaching strategies are aligned towards creating a deeper approach to learning the students' preferred approach can also change causing an impact on the outcomes.

\section{METHOD}

This study was conducted in the School of Computer Technology at a private university college in the Klang valley. Biggs et al., (2001) 'Revised Two-Factor Study Process Questionnaire (R-SPQ2F)' was used to explore students' approaches to learning from the students' perspective. This instrument measures two latent variables: 
a deep approach to learning (10 items) and a surface approach to learning (10 items) as indicated in Table 2 and Table 3. The deep approach latent variable was indicated by two observed variables (Deep Motive and Deep Strategy sub-scales), while the surface approach latent variable was indicated by another two observed variables (Surface Motive and Surface Strategy subscales). The items were rated on a Likert scale $(1-$ never or only rarely true of me, 2 - sometimes true of me, 3 - true of me about half the time, $4-$ frequently true of me, 5 - always or almost always true of me).

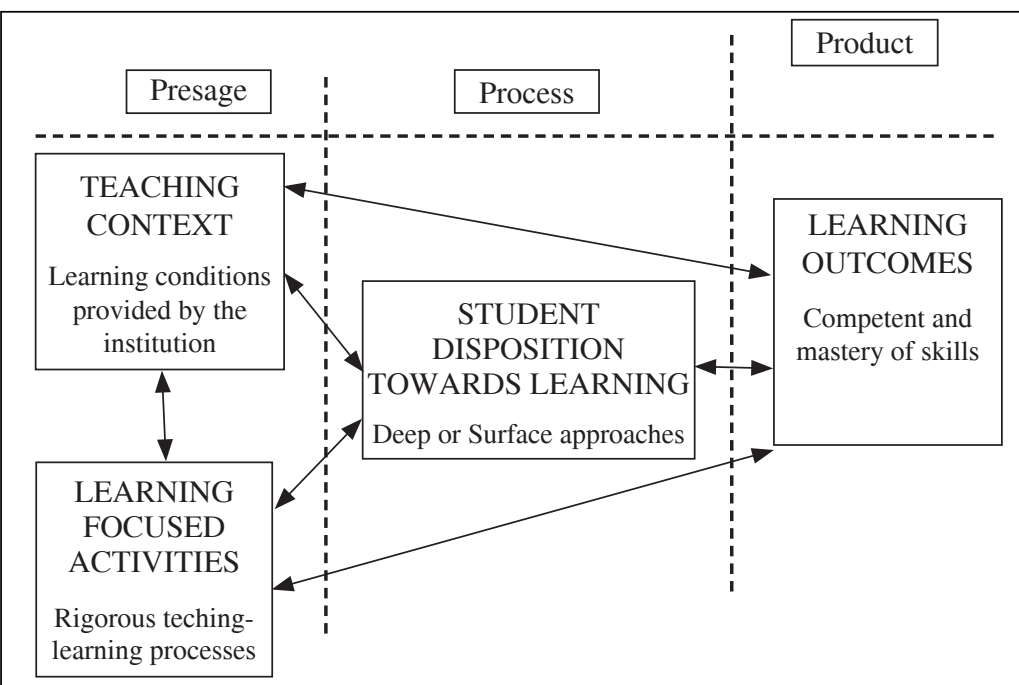

Adapted from the ' $3 \mathrm{P}$ ' model of teaching and learning by Biggs, Kember, \& Leung (2001)

Figure 1. Teaching context, learning activities, and student outcomes.

The participants for this study were undergraduates students taking courses in Information Systems, Information Technology, and Multimedia Systems. Questionnaires were distributed to all the 200 students enrolled at the School. Out of the 200 questionnaires distributed, 80 were returned, but only 63 were usable for the analysis. The sample distribution according to gender, nationality, year of study and degree major is given in Table 1 . 
Table 1

Demographic Information

\begin{tabular}{|c|c|c|c|c|c|c|c|c|c|}
\hline \multicolumn{2}{|c|}{ Gender } & \multicolumn{2}{|c|}{ Nationality } & \multicolumn{3}{|c|}{ Year of Study } & \multicolumn{3}{|c|}{ Degree Major } \\
\hline Male & Female & Local & International & Year 1 & Year 2 & Year 3 & $\begin{array}{l}\text { Info } \\
\text { System }\end{array}$ & $\begin{array}{c}\text { Info } \\
\text { Technology }\end{array}$ & $\begin{array}{c}\text { Multimedia } \\
\text { System }\end{array}$ \\
\hline 49 & 14 & 39 & 24 & 33 & 19 & 11 & 40 & 14 & 9 \\
\hline
\end{tabular}

\section{FINDINGS}

Independent $t$-tests and one-way ANOVA showed no significant difference between the types of approach used and the demographic variables of gender, nationality, year of study, and degree major. However, the rank ordering of the mean value indicated that almost every one of the participants in the study were somewhere in between deep and surface, and clearly did not possess the deep approach to learning. As a first step in the analysis, the mean score value was found for all the 20 items. The cumulative mean value for the 'Deep Approach' items was 3.01 (Table 2) and the cumulative mean value for the 'Surface Approach' was 2.91 (Table 3).

Table 2

Deep Approach to Learning

\begin{tabular}{llcc}
\hline No & \multicolumn{1}{c}{ Deep Approach Items } & $\begin{array}{c}\text { Mean } \\
\text { Score }\end{array}$ & $S D$ \\
\hline $1 \quad \begin{array}{l}\text { I find that at times studying gives me a feeling of deep } \\
\text { personal satisfaction. }\end{array}$ & 2.89 & 1.05 \\
2 & $\begin{array}{l}\text { I find that I have to do enough work on a topic so that I can } \\
\text { form my own conclusions before I am satisfied. }\end{array}$ & 3.27 & 1.00 \\
$5 \quad \begin{array}{l}\text { I feel that virtually any topic can be highly interesting once } \\
\text { I get into it. }\end{array}$ & 3.22 & 1.05 \\
$6 \quad \begin{array}{l}\text { I find most new topics interesting and often spend extra time } \\
\text { trying to obtain more information about them. }\end{array}$ & 3.29 & 1.16 \\
$9 \quad \begin{array}{l}\text { I find that studying academic topics can at times be as } \\
\text { exciting as a good novel or movie. }\end{array}$ & 2.76 & 1.17 \\
\hline
\end{tabular}




\begin{tabular}{llcc}
\hline No & \multicolumn{1}{c}{ Deep Approach Items } & $\begin{array}{c}\text { Mean } \\
\text { Score }\end{array}$ & $S D$ \\
\hline 10 & $\begin{array}{l}\text { I test myself on important topics until I understand them } \\
\text { completely. }\end{array}$ & 3.14 & 1.08 \\
13 & $\begin{array}{l}\text { I work hard at my studies because I find the material } \\
\text { interesting. }\end{array}$ & 2.98 & 0.99 \\
14 & $\begin{array}{l}\text { I spend a lot of my free time finding out more about } \\
\text { interesting topics which have been discussed in different } \\
\text { classes. }\end{array}$ & 1.18 \\
17 & $\begin{array}{l}\text { I come to most classes with questions in mind that I want } \\
\text { answering. }\end{array}$ & 2.71 & 1.05 \\
18 & $\begin{array}{l}\text { I make a point of looking at most of the suggested readings } \\
\text { that go with the lectures. }\end{array}$ & 2.97 & 1.05 \\
\hline $\begin{array}{l}\text { Deep Approach (DA) }=1+2+5+6+9+10+13+14+ \\
17+18\end{array}$ & $\mathbf{3 . 0 1}$ & \\
\hline
\end{tabular}

These two mean values indicated that the students in the study did not fall strongly on either the deep approach side or the surface approach side. They mainly fell in the middle indicating that this was true of them half the time and not always. This result indicated that activities focused on learning could be scarce, and the teaching context not very supportive of developing students' deep learning.

\section{Table 3}

\section{Surface Approach to Learning}

\begin{tabular}{llcc}
\hline No & \multicolumn{1}{c}{ Surface Approach Items } & $\begin{array}{c}\text { Mean } \\
\text { Score }\end{array}$ & $S D$ \\
\hline 3 & $\begin{array}{l}\text { My aim is to pass the course while doing as little work as } \\
\text { possible. }\end{array}$ & 2.83 & 1.39 \\
4 & $\begin{array}{l}\text { I only study seriously what's given out in class or in the } \\
\text { course outlines. }\end{array}$ & 2.95 & 1.22 \\
7 & $\begin{array}{l}\text { I do not find my course very interesting so I keep my work } \\
\text { to the minimum. }\end{array}$ & 2.65 & 1.12 \\
8 & $\begin{array}{l}\text { I learn some things by rote, going over and over them until I } \\
\text { know them by heart even if I do not understand them. }\end{array}$ & 2.97 & 1.08 \\
11 & $\begin{array}{l}\text { I find I can get by in most assessments by memorizing key } \\
\text { sections rather than trying to understand them. }\end{array}$ & 2.97 & 1.03 \\
12 & $\begin{array}{l}\text { I generally restrict my study to what is specifically set as I } \\
\text { think it is unnecessary to do anything extra. }\end{array}$ & 2.98 & 1.13 \\
\hline
\end{tabular}




\begin{tabular}{llcc}
\hline No & \multicolumn{1}{c}{ Surface Approach Items } & $\begin{array}{c}\text { Mean } \\
\text { Score }\end{array}$ & $S D$ \\
\hline 15 & $\begin{array}{l}\text { I find it is not helpful to study topics in depth. It confuses } \\
\text { and wastes time, when all you need is a passing acquain- } \\
\text { tance with topics. }\end{array}$ & 2.79 & 1.11 \\
16 & $\begin{array}{l}\text { I believe that lecturers shouldn't expect students to spend } \\
\text { significant amounts of time studying material everyone } \\
\text { knows won't be examined. }\end{array}$ & 3.05 & 1.13 \\
19 & $\begin{array}{l}\text { I see no point in learning material which is not likely to be } \\
\text { in the examination. }\end{array}$ & 3.08 & 1.26 \\
20 & $\begin{array}{l}\text { I find the best way to pass examinations is to try to remem- } \\
\text { ber answers to likely questions. }\end{array}$ & 3.16 & 1.08 \\
\hline & $\begin{array}{l}\text { Surface Approach (SA) }=3+4+7+8+11+12+15+ \\
16+19+20\end{array}$ & $\mathbf{2 . 9 4}$ & \\
\hline
\end{tabular}

A Pearson product-moment correlation was done to see whether there is any relationship among strategy, motives and approach scores. Results are shown in Table 4. (Table 4).

\section{Table 4}

Relationship among Motives, Strategies, and Approaches

\begin{tabular}{|c|c|c|c|c|c|c|}
\hline & $\begin{array}{c}\text { Deep } \\
\text { Approach }\end{array}$ & $\begin{array}{l}\text { Surface } \\
\text { Approach }\end{array}$ & $\begin{array}{c}\text { Deep } \\
\text { Motive }\end{array}$ & $\begin{array}{c}\text { Deep } \\
\text { Strategy }\end{array}$ & $\begin{array}{l}\text { Surface } \\
\text { Motive }\end{array}$ & $\begin{array}{l}\text { Surface } \\
\text { Strategy }\end{array}$ \\
\hline Deep Approach & 1 & & & & & \\
\hline Surface Approach & -0.041 & & & & & \\
\hline Deep Motive & $0.887^{\text {*** }}$ & -0.155 & & & & \\
\hline Deep Strategy & $0.903^{* *}$ & 0.073 & $0.602^{* *}$ & & & \\
\hline Surface Motive & 0.150 & $0.932^{* *}$ & -0.232 & -0.044 & & \\
\hline Surface Strategy & 0.084 & $0.919^{* *}$ & -0.047 & 0.188 & $.713^{* *}$ & 1 \\
\hline
\end{tabular}

**. Correlation is significant at the .01 level (2-tailed).

The Pearson's $r$ correlation analysis revealed a weak negative statistical correlation between the deep and surface approaches to learning $(r=-.041, p<.01)$ and weak positive statistical correlation between surface strategy $(r=.084, p<.01)$ and deep approach. But a significant relationship between deep strategy and deep approach $\left(r=.903^{* *}, p<.01\right)$ was found. This shows that an increase in students' deep strategies leads to deep approaches to learning. The strategies that might have led to these are more 
reading, searching of information, and the quality and rigor of assignments, and so forth. There also exist a significant relationship between surface approach, surface motive and surface strategy. However, the correlation is higher with surface motive and surface approach. This can be due to an increase in student's motive to use subject requirements minimally rather than a reduction in their use of surface strategies such as memorization and reproduction. Identifying this may help teachers to motivate students to improve on their motives to use deep approaches and engage in using deep strategies in learning.

\section{DISCUSSION}

From the results of this study, it is evident that the Computing School students were not adopting the deep approach fully in their learning. This can be attributed to three inter-related aspects, namely, the student factor, the teaching context, and the learning activities or the tasks (Biggs, 2001). The student factor may include the prior knowledge or past learning experiences of students that determine the kind of approach they bring with them. The teaching context may include the learning objectives, the assessment methods, school climate or the ethos, pedagogical practices, and institutional procedures while the learning activities refer to the tasks assigned and the quality and rigor of the teaching-learning process. The activity of guiding students towards deep approaches is a multi-level task. It involves the creation of learning conditions that challenge students' critical thinking and creative ability, the availability of the teachers who are competent in providing deep and meaningful learning activities that may provide rich learning experiences, and rigorous instructional practices that are engaging and challenging to students.

\section{Learning Conditions}

Two conditions, internal and external are said to determine student learning (Dewey, 1964). Students' motivation and the teachinglearning environment were found to be the two influencing factors in students' approach to learning (Howe, 1999; Kember et al., 1994). It is critical that an educational institution aiming to cultivate 
deep approaches among students look into developing motivation and aspiration for high quality academic achievement. The pressure for higher standards is usually accompanied by increased number of assignments, long hours of reading, library research, and more in-depth analysis of subject matter. This can be a daunting experience to many and personal support of teachers can be helpful in keeping student morale and motivation high. Personal encouragement, positive reinforcement, affirmation of student work, and showing genuine concern can help build students' motivation to strive for higher quality learning and better outcomes. In addition to the internal conditions, it also becomes the responsibility of an educational institution to provide the appropriate physical, psychosocial, and cultural support to students. Providing an environment where students feel "safe" to explore and experiment with new ideas and creating platforms to share and voice their opinions freely can allow the development of deep approaches among students. Academic dialogue sessions, seminars, discussion groups, invited speaker sessions, forums, and symposiums can provide the opportunity for intellectual robustness and deep approaches towards learning.

\section{Professional Capacity}

Teachers are the driving force behind any successful learning activity. Quality of education, level of preparedness, and positive disposition of teachers become the determining factors in helping students achieve deep approaches in learning (Kember, 2000). Teachers' knowledge base, well-grounded in subject matter knowledge, curricular knowledge, pedagogical knowledge, and knowledge about the learners and their contexts are central to effective teaching and learning (Ball \& Forzani, 2007; Ball, Thames, \& Phelps, 2008; Darling-Hammond \& Bransford, 2006; Grossman, 1990). Competent teachers who possess specialized content knowledge formulate rigorous instructional activities, deliver it in engaging ways, design assignments that will challenge students to question their own thinking processes, encourage metacognitive analysis, motivate students to master higher order thinking skills and apply them to solve complex problems (Ball et al., 2008). Clearly, recruiting and developing teachers who are competent are crucial for developing deep approach in students. 


\section{Instructional Rigor}

Academic depth and rigor is clearly a critical element in the development of the deep approach in learning among students. This can be achieved by establishing a coherent instructional practice focused on explicit student learning outcomes, a detailed description of the high quality instructional procedures that will lead to the attainment of learning outcomes, materials and associated tools relevant to instruction, and assessment methods that will contribute towards deep approaches. The organization of the curriculum content aligned with the learning outcomes, and the instructional strategies with the right kind of materials and general pedagogies can result in a rigorous teaching-learning experience. The rigor of learning can be further enhanced through applying assessment methods focused on developing deep approaches. The quality of the learning tasks assigned, assessment method used, types of work to be produced, and how students are graded and supplied with feedback can improve the overall instructional practice and student learning outcomes (Biggs, 1987; Dornyei, 2000; Jacobs \& Newstead, 2000). The high-quality instructional practices that are intellectually engaging and challenging will create the opportunity for developing deep approach among students (Gijbels \& Dochy, 2006).

\section{CONCLUSION}

Students must depart from the surface approach to learning that is focused on a narrow target and rote method and strive for the deep approach which pushes for maximization of meaning and conceptual understanding of a subject. It is not sufficient that students merely pass an examination; they must be able to fulfill the intrinsic interest to acquire in-depth knowledge for better performance and acquire the competencies in analyzing, evaluating, and synthesizing ideas. However, student learning is influenced by a number of factors such as students' values and motives, their perceptions of task demands, teaching and assessments methods, the teaching-learning climate, teacher preparedness and the quality of institutional procedures (Biggs et al., 2001). Students' shift from surface approach to deep approach in learning can be achieved by improving the conditions for learning, raising teacher professional capacity, and scaling up the 
instructional rigor of programs offered (Hargreaves \& Fullan, 2012). Better motivation and morale, and the physical, cultural, and psychosocial support provided will improve students' approach to learning. This can be enhanced further with teachers who are better prepared in their specialized content knowledge as well as pedagogical content knowledge to elevate students' learning (Darling-Hammond $\&$ Bransford, 2006; Grossman, 1990). Scaling up of the instructional routines that include the appropriate methodology and assessment is also an important component in developing the students' deep approaches to learning. These three aspects, done with care, can help bring about positive changes in the teaching-learning process and the approach to learning as well as better outcomes.

\section{REFERENCES}

Ball, D. L., \& Forzani, F. (2009). The work of teaching and the challenge for teacher education. Journal of Teacher Education, 60(5), 497-511.

Ball, D. L., Thames, M. H., \& Phelps, G. (2008). Content knowledge for teaching: What makes it special? Journal of Teacher Education, 59(5), 389-407.

Biggs, J. B. (1987). Student approaches to learning and studying. Hawthorne, Victoria: Australian Council for Educational Research.

Biggs, J. (1999). Teaching for quality learning at university. Buckingham: Open University Press.

Biggs, J. B., Kember, D., \& Leung, D. (2001). The revised two-factor study process questionnaire: R-SPQ-2F. British Journal of Educational Psychology, 71, 133-149.

Darling-Hammond, L., \& Bransford, J. (2006). Preparing teachers for a changing world: What teachers should learn and be able to do. San Francisco, CA: Jossey-Bass.

Dewey, J. J. (1964). The child and the curriculum. In R. Archambault (Ed.), John Dewey on education: Selected writings. Chicago, IL: University of Chicago Press.

Dornyei, Z. (2000). Motivation in action: Towards a processoriented conceptualization of student motivation. British Journal of Educational Psychology, 79, 519-538.

Entwistle, N. J. (1987). A model of the teaching-learning process. In J. T. E. Richardson, M. W. Eysenck, \& D. Warren Piper (Eds.), Student learning: Research in higher education and 
cognitive psychology (pp. 13-28). Milton Keynes, UK: SRHE and Open University Press.

Entwistle, N. J. (1991). Approaches to learning and perceptions of the learning environment. Higher Education, 22, 201-204.

Gijbels, D., \& Dochy, F. (2006). Student's assessment preferences and approaches to learning: Can formative assessment make a difference? Educational Studies, 32(4), 399-409.

Grossman, P. L. (1990). The making of a teacher: Teacher knowledge and teacher education. New York, NY: Teachers College Press.

Hargreaves, A., \& Fullan, M. (2012). Professional capacity: Transforming teaching in every school. New York: Teachers College Press.

Howe, M. J. A. (1999). Genius explained. Cambridge, UK: Cambridge University Press.

Jacobs, P. A., \& Newstead, S. (2000). The nature and development of student motivation. British Journal of Education Psychology, 20, 243-254.

Kember, D. (2000). Action learning and action research: Improving the quality of teaching and learning. London, UK: Kogan Page.

Kember, D., Charlesworth, M., Davies, H., McKay, J., \& Stott, V. (1994). Evaluating the effectiveness of educational innovations: Using the study process questionnaire to show that meaningful learning occurs, 141-157. Retrieved from http://www.elsevier.com/locate/studeduc

Kember, D., \& Gow, L. (1991). A challenge to the anecdotal stereotype of the Asian student. Studies in Higher Education, 16(2), 117-128.

Khoo, H. C. (2001). Graduating into IT industry. Education Quarterly, 19, 14-15.

Koo, Y. L., Pang, V., \& Mansur, F. (2006). Employer perception on graduate literacies in higher education in relation to the workplace, 1-16. Retrieved from http://www.esp-world.info/Articles

Kumar, L. R., \& Sethuraman, K. R. (2007). Learning approaches in dental and medical students in AIMST: A comparison between deep and surface approaches. International Medical Education Conference.

Ling, P., Arger, G., Filonenko, I., Chua, H., \& Yin, C. (2005). Approaches to study: A comparison of Malaysian and Australian students. In Higher education in a changing world, Proceedings of the 28th HERDSA Annual Conference, Sydney, 3-6 July 2005: 276-286. 
National Higher Education Research Institute. (2007). University education curricula and workplace literacy. Penang, Malaysia: Universiti Sains Malaysia.

Raadt. D. M, Hamilton. M., \& Lister, R. (2005). Approaches to learning in Computer Programming students and their effect on success. HERDSA conference proceedings.

Tan, S. C. (2007). Be more prepared. The Sunday Star. Retrieved from http://thestar.com.my

Wilson, K. L., Smart, R. M., \& Watson, R. J. (1996).Gender differences in approaches to learning in first-year psychology students. British Journal of Educational Psychology, 66, 59-71.

Woo. K. Y. (2006). Malaysian private higher education: A need to study the different interpretations of quality. JASA, Review papers, 17-21.

Zeegers, P. (2001). Student learning in science: A longitudinal study. British Journal of Educational Psychology, 71, 115-132. 